\title{
Intoxication of mammalian cells with binary clostridial enterotoxins is inhibited by the combination of pharmacological chaperone inhibitors
}

\author{
Katharina Ernst ${ }^{1}$ (D) Judith Sailer ${ }^{1} \cdot$ Maria Braune $^{1} \cdot$ Holger Barth $^{1}$ (D) \\ Received: 7 May 2020 / Accepted: 18 November 2020 / Published online: 7 December 2020 \\ (C) The Author(s) 2020
}

\begin{abstract}
Binary enterotoxins Clostridioides difficile CDT toxin, Clostridium botulinum $\mathrm{C} 2$ toxin, and Clostridium perfringens iota toxin consist of two separate protein components. The B-components facilitate receptor-mediated uptake into mammalian cells and form pores into endosomal membranes through which the enzymatic active A-components translocate into the cytosol. Here, the A-components ADP-ribosylate G-actin which leads to F-actin depolymerization followed by rounding of cells which causes clinical symptoms. The protein folding helper enzymes Hsp90, Hsp70, and peptidyl-prolyl cis/trans isomerases of the cyclophilin (Cyp) and FK506 binding protein (FKBP) families are required for translocation of A-components of CDT, C2, and iota toxins from endosomes to the cytosol. Here, we demonstrated that simultaneous inhibition of these folding helpers by specific pharmacological inhibitors protects mammalian, including human, cells from intoxication with CDT, C2, and iota toxins, and that the inhibitor combination displayed an enhanced effect compared to application of the individual inhibitors. Moreover, combination of inhibitors allowed a concentration reduction of the individual compounds as well as decreasing of the incubation time with inhibitors to achieve a protective effect. These results potentially have implications for possible future therapeutic applications to relieve clinical symptoms caused by bacterial toxins that depend on Hsp90, Hsp70, Cyps, and FKBPs for their membrane translocation into the cytosol of target cells.
\end{abstract}

Keywords Bacterial protein toxins $\cdot$ Pharmacological inhibitors $\cdot$ Chaperones $\cdot$ Cellular uptake $\cdot$ Clostridioides difficile $\cdot$ CDT toxin

\section{Introduction}

Clostridioides difficile toxin CDT, Clostridium botulinum C2 toxin, and Clostridium perfringens iota toxin are members of the family of binary actin-ADP-ribosylating toxins that cause enterotoxicity in humans and animals (Ohishi 1983; Songer 1996; Papatheodorou et al. 2018). These protein toxins consist of two separate proteins that are secreted by the bacteria and

Katharina Ernst and Judith Sailer contributed equally to this work.

Katharina Ernst

katharina.ernst@uni-ulm.de

Holger Barth

holger.barth@uni-ulm.de

1 Institute of Pharmacology and Toxicology, Ulm University Medical Center, 89081 Ulm, Germany share a widely common cellular uptake mechanism and mode of action. The binding/translocation (B) component mediates the transport of the enzymatically active (A) component into the cytosol of target cells. Here, the A-component monoADP-ribosylates G-actin (Aktories et al. 1986; Schering et al. 1988; Popoff et al. 1988). This leads to depolymerization and destruction of actin filaments and causes rounding of adherent cells (Reuner et al. 1987; Wegner and Aktories 1988; Aktories and Wegner 1992). In vivo, rounding of epithelial cells in the intestine results in impairment of the gut barrier and thereby elicits clinical symptoms of enterotoxicity.

The $\mathrm{C} 2$ toxin is the prototype of this toxin family and its cellular uptake was studied in more detail. The B-component of $\mathrm{C} 2$ toxin C2II gets proteolytically activated (Barth et al. 2000). The resulting biologically active C2IIa forms heptameric complexes that bind to asparagine-linked carbohydrate structures that are located on the surface of all cell types (Ohishi et al. 1984; Eckhardt et al. 2000; Blöcker et al. 2000). 
C2I, the A-component, binds to C2IIa-heptamers and the complex is taken up into cells by receptor-mediated endocytosis. Vesicular ATPases cause acidification of the toxinloaded endosomes. This leads to conformational changes of both components: the C2IIa-heptamer forms a translocation pore into the endosomal membrane and C2I is partially unfolded to translocate through the narrow pore into the cytosol of target cells (Barth et al. 2000; Haug et al. 2003b; Schleberger et al. 2006).

Cellular uptake and mode of action of the iota toxin and CDT are widely comparable and show some differences to $\mathrm{C} 2$ toxin. The B-components $\mathrm{Ib}$ and $\mathrm{CDTb}$, respectively, facilitate the transport of the A-components Ia and CDTa into the cytosol ((Stiles and Wilkins 1986; Perelle et al. 1997) for review see (Barth and Stiles 2008; Barth and Ernst 2016)). Iota toxin and CDT are closely related and form the sub-group of iota-like toxins within the binary ADP-ribosylating toxins. They both bind to the lipolysisstimulated lipoprotein receptor (LSR) and use CD44 as a co-receptor for cellular uptake (Papatheodorou et al. 2011; Wigelsworth et al. 2012).

During the last years, we showed that $\mathrm{C} 2$, iota, and CDT toxins require the assistance of folding helper enzymes for translocation of their A-components from endosomes to the cytosol (Barth and Ernst 2016; Ernst et al. 2017b, a). The chaperones heat shock protein (Hsp) 90 and 70, as well as isoforms of cyclophilins (Cyps) and FK506-binding proteins (FKBPs) facilitate the translocation of partially unfolded C2I, Ia, and CDTa through the respective pores into the cytosol (Haug et al. 2003a, 2004; Kaiser et al. 2009, 2011, 2012; Ernst et al. 2015, 2016, 2017a). Cyps and FKBPs are peptidyl-prolyl cis/trans isomerases (PPIases) that catalyze the rate-limiting step of cis/trans isomerization of prolylbond during protein folding (Schiene-Fischer 2014). Treatment of cells with specific pharmacological inhibitors blocks activity of folding helpers, which protects cells as well as more complex models like human intestinal organoids from intoxication with clostridial binary toxins. Radicicol (Rad) and VER-155008 (VER) inhibit activity of Hsp90 and Hsp70, respectively, by binding to their ATP-binding pockets. Cyclosporine A (CsA) and FK506 prevent activity of Cyps and FKBPs, respectively (Barth and Ernst 2016). Previously, we showed that combining all four inhibitors results in an enhanced protection of cells from intoxication with $\mathrm{C} 2$ toxin compared to application of the single inhibitors (Ernst et al. 2018b). Here, prompted by these earlier findings, we demonstrated that the inhibitor combination exhibits an enhanced inhibitory effect on CDT intoxication of cells. Since CDT contributes to the severe diseases caused by hyper-virulent CDT-expressing strains of $C$. difficile including the pseudomembranous colitis, the results can be a starting point for the development of novel pharmacological options to treat and/or prevent the diseases associated with CDT.

\section{Materials and methods}

\section{Protein expression and purification}

Protein toxin components were purified and activated as described before: C2I and C2IIa (Barth et al. 1998), CDTa and CDTb (Papatheodorou et al. 2010), Ia and Ib (Perelle et al. 1997).

\section{Cell culture}

Cells were detached by trypsin and reseeded every $2-3$ days for no more than 25 times. Incubation of cells occurred at $37^{\circ} \mathrm{C}$ and $5 \% \mathrm{CO}_{2}$ under humidified conditions. Vero cells (African green monkey kidney cells, DSMZ, Braunschweig, Germany) were cultured in MEM plus $10 \%$ heat-inactivated fetal calf serum (FCS) (GIBCO life technologies, Karlsruhe, Germany), $0.1 \mathrm{mM}$ non-essential amino acids, $1 \mathrm{mM}$ sodium pyruvate, $2 \mathrm{mM} \mathrm{L}$-glutamine, and $100 \mathrm{U} / \mathrm{mL}$ of penicillin and $100 \mu \mathrm{g} / \mathrm{mL}$ of streptomycin. CaCo-2 cells (human epithelial colorectal adenocarcinoma cells, ATCC HTB-37, Manassas, VA, USA) were cultured in DMEM (GIBCO life technologies, Karlsruhe, Germany) plus 10\% FCS, $1 \mathrm{mM}$ sodium pyruvate, $0.1 \mathrm{mM}$ non-essential amino acids, and $100 \mathrm{U} / \mathrm{mL}$ of penicillin and $100 \mu \mathrm{g} / \mathrm{mL}$ of streptomycin.

\section{Intoxication experiments}

Cells were seeded into 24-well culture dishes. The following inhibitors of host cell chaperones were used: Rad (inhibitor of Hsp90), CsA (inhibitor of Cyps), and FK506 (inhibitor of FKBPs) were purchased from Sigma-Aldrich (Merck, Darmstadt, Germany), VER (inhibitor of Hsp70, Hsc70 and Grp78) was purchased from Tocris Bioscience (WiesbadenNordenstadt, Germany). Bafilomycin A1 (BafA1, inhibitor of v-ATPase) was obtained from Calbiochem (Bad Soden, Germany). After pre-incubation of cells with inhibitors, toxin components were added. Images of cells were obtained using a Zeiss (Oberkochen, Germany) Axiovert 40CFL microscope with a Jenoptik (Jena, Germany) ProGres C10 CCD camera. Morphological changes induced by the toxins were analyzed by counting cells showing intoxication morphology (formation of protrusions, rounding of cells) and determining the percentage of intoxicated cells (Image J, National Institutes of Health, Bethesda, USA). Culture dishes and well plates were purchased from TPP Techno Plastic Products (Trasadingen, Switzerland).

\section{Analysis of ADP-ribosylation status of G-actin}

CaCo-2 cells were pre-incubated with respective inhibitor combination and then intoxicated with CDT for given incubation periods. Cells were lysed in ADP-ribosylation buffer ( $1 \mathrm{mM}$ DTT, $5 \mathrm{mM} \mathrm{MgCl}$ and $1 \mathrm{mM}$ EDTA, $20 \mathrm{mM}$ Tris$\mathrm{HCl} \mathrm{pH} 7.5$ plus complete protease inhibitor (Roche, 
Mannheim, Germany)), followed by incubation with $100 \mathrm{ng}$ CDTa and $10 \mu \mathrm{M}$ biotin-labeled $\mathrm{NAD}^{+}$(Trevigen, Gaithersburg, MD, USA) for $30 \mathrm{~min}$ at $37{ }^{\circ} \mathrm{C}$ for in vitro ADP-ribosylation of G-actin, which had not yet been ADPribosylated by CDTa during the previous incubation. Samples were subjected to SDS-PAGE, blotted, and ADP-ribosylated, i.e., biotin-labeled; G-actin was detected with streptavidinperoxidase (Strep-POD, Sigma-Aldrich, Merck) using the ECL system. Equal amounts of protein loading were confirmed by ponceau S staining. Intensity of Western blot signals were quantified densitometrically and normalized to loading controls (ponceau $\mathrm{S}$ signals). Additionally, values were normalized to untreated control samples.

\section{TEER measurements}

$\mathrm{CaCo} 2$ cells were seeded into 24-well hanging cell culture inserts (Millicell Cell Culture Inserts, EMD Millipore Corporation, Burlington, MA, USA). $1.1 \times 10^{5}$ cells per filter were seeded. A dense monolayer was obtained after growing cells for 3-4 days. Fresh medium with or without inhibitors was added in a fresh 24-well plate and hanging inserts with cell monolayers were placed into the fresh medium. BafA1 is an inhibitor of vesicular ATPases and thereby also inhibits uptake of CDT, C2, and other toxins that escape from acidified endosomes. BafA1 was used as a positive control for inhibition of toxin uptake (Barth et al. 2000). After $30 \mathrm{~min}$ of pre-incubation at $37{ }^{\circ} \mathrm{C}$, toxin components were added apically. TEER was measured every $30 \mathrm{~min}$ with the EVOM2 Voltohmmeter (World Precision Instruments, Friedberg, Germany). Raw data of resistance were transformed to unit area resistance by subtracting blank resistance and multiplying resulting data with effective surface area of used hanging insert membrane (here $0.3 \mathrm{~cm}^{2}$ ). Values were normalized to their respective starting value $\left(t_{0}\right)$.

\section{Cell viability}

Vero cells were seeded into a 96-well plate. Cells were incubated with chaperone inhibitors at indicated concentrations for $6 \mathrm{~h}$. Images were taken, then cells were washed to remove precipitation of inhibitors which occurred at higher concentrations. Then, MTS reagent (Promega, Mannheim, Germany) was added and after incubation for $1 \mathrm{~h}$ at $37^{\circ} \mathrm{C}$, absorbance at $490 \mathrm{~nm}$ was measured. Values were normalized to untreated control cells (control $=100 \%$ ). Results from 4 independent experiments with triplicates are shown.

\section{Reproducibility of experiments}

All experiments were performed independently at least two times. Results from representative experiments are shown in figures if not indicated otherwise.

\section{Results}

\section{Combination of pharmacological inhibitors shows a more pronounced delay of CDT intoxication than application of the respective individual inhibitors}

Intoxication of adherent cells like Vero cells with CDT leads to specific morphological changes, i.e., rounding of cells. This is a direct effect of the mode of action of CDT and other actinADP-ribosylating toxins like $\mathrm{C} 2$ and iota toxin and is used as a robust and highly specific endpoint to determine the degree of intoxication. Images in Fig. 1a show that CDT caused rounding of cells after $2 \mathrm{~h}$ of intoxication. The percentage of cells showing this change in morphology was determined from the pictures (Fig. 1b). If cells were pre-incubated with the single chaperone and PPIase inhibitors, a delay in intoxication was observed after $2 \mathrm{~h}$. A comparable effect was achieved if all four inhibitors were applied in combination. However, after longer incubation periods, only the combination of inhibitors and not the inhibitors alone caused a delay in intoxication (Figs. 1b, c). The solvents of the inhibitors had no effect on CDT intoxication (supplemental Fig. 1).

\section{Combined pharmacological inhibition of chaperones/PPlases delays intoxication with CDT in a human colon epithelial cell line}

A delay in CDT intoxication by the inhibitor combination was also observed in the human colon carcinoma cell line $\mathrm{CaCo}-2$ (Fig. 2a). Since the protective effect on cell morphology was not as clearly observable in CaCo-2 cells as in Vero cells, we analyzed the ADP-ribosylation status of G-actin in these cells to confirm the results. Therefore, cells were lysed and subsequently incubated with fresh CDTa plus biotin-labeled $\mathrm{NAD}^{+}$ in vitro. This leads to ADP-riboslyation of the portion of Gactin that has not been modified in the living cells before. The presence of biotin-labeled NAD ${ }^{+}$results in biotin-labeling of that portion of G-actin which was detected by Western blot. Therefore, a strong signal in the blot indicates no modification of actin in the living cells, which was observed for untreated control samples (Fig. 2b). A weak signal means that most of the actin has been ADP-ribosylated by the toxin in the living cells thus, could not serve as a substrate in the in vitro ADPribosylation. In samples that have been treated with only CDT, no signal was detectable. Samples pre-treated with the lower concentration of the inhibitor combination prior to CDT intoxication showed a weak signal. However, this signal was comparable to samples treated with only solvent and CDT. A significantly increased signal was obtained in samples treated with the higher concentration of inhibitors and CDT, even in comparison to the respective solvent control. Figure $2 \mathrm{~b}$ shows the result of one representative experiment. Since the protein loading of the samples slightly varied between the different 
Fig. 1 Combined

pharmacological inhibition of Hsp90, Hsp70, Cyps, and FKBPs delays intoxication of Vero cells with CDT. Vero cells were preincubated at $37{ }^{\circ} \mathrm{C}$ for $30 \mathrm{~min}$ with the single inhibitors or a combination of the inhibitors (CsA $20 \mu \mathrm{M}$, FK506 $20 \mu \mathrm{M}$, radicicol $20 \mu \mathrm{M}$ and VER $30 \mu \mathrm{M})$. Cells were then challenged with $50 \mathrm{ng} / \mathrm{mL} \mathrm{CDTa}+$ $100 \mathrm{ng} / \mathrm{mL}$ CDTb. For control, cells were left untreated or treated only with CDT. Cells were further incubated at $37^{\circ} \mathrm{C}$ and images were taken at the indicated time points. a Images show the morphological changes induced by the toxin after $2 \mathrm{~h}$ of incubation. $\mathbf{b}$ Percentage of cells with morphological changes was determined from images at the indicated time points. Values are given as mean $\pm \mathrm{SD}(n=3)$. Significance was tested using two-way ANOVA followed by Dunnett's multiple comparison test. (* $p \leq 0.05$, ** $p \leq 0.01$, **** $p \leq 0.0001$, ns, not significant vs CDT + combi). c Time course of intoxication with CDT determined from images a

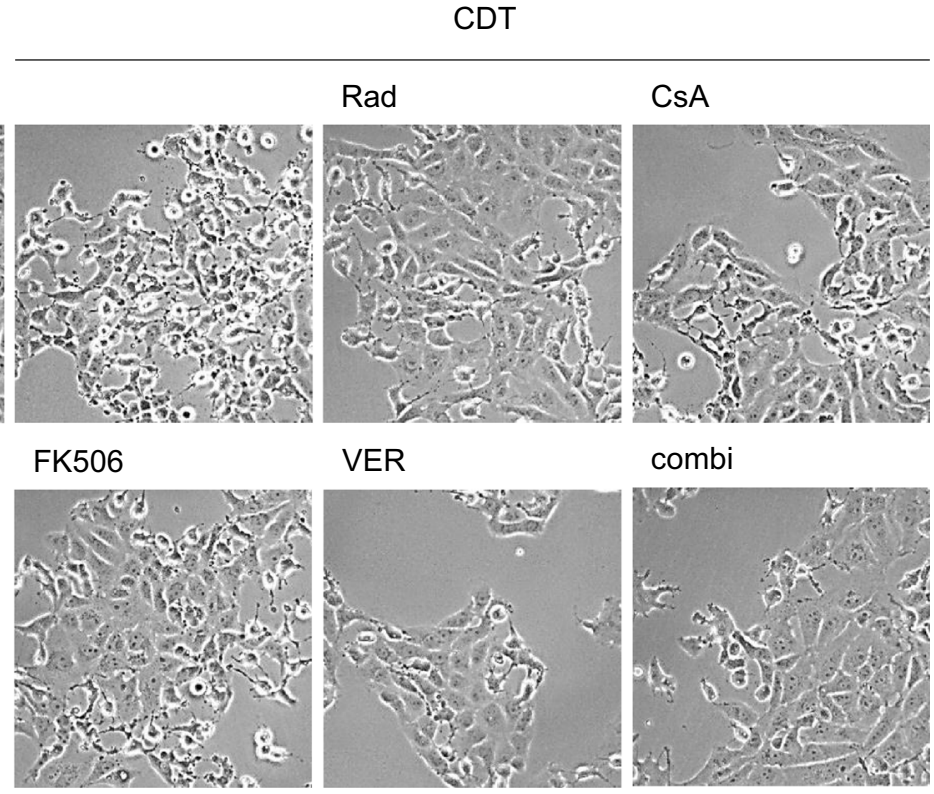

b
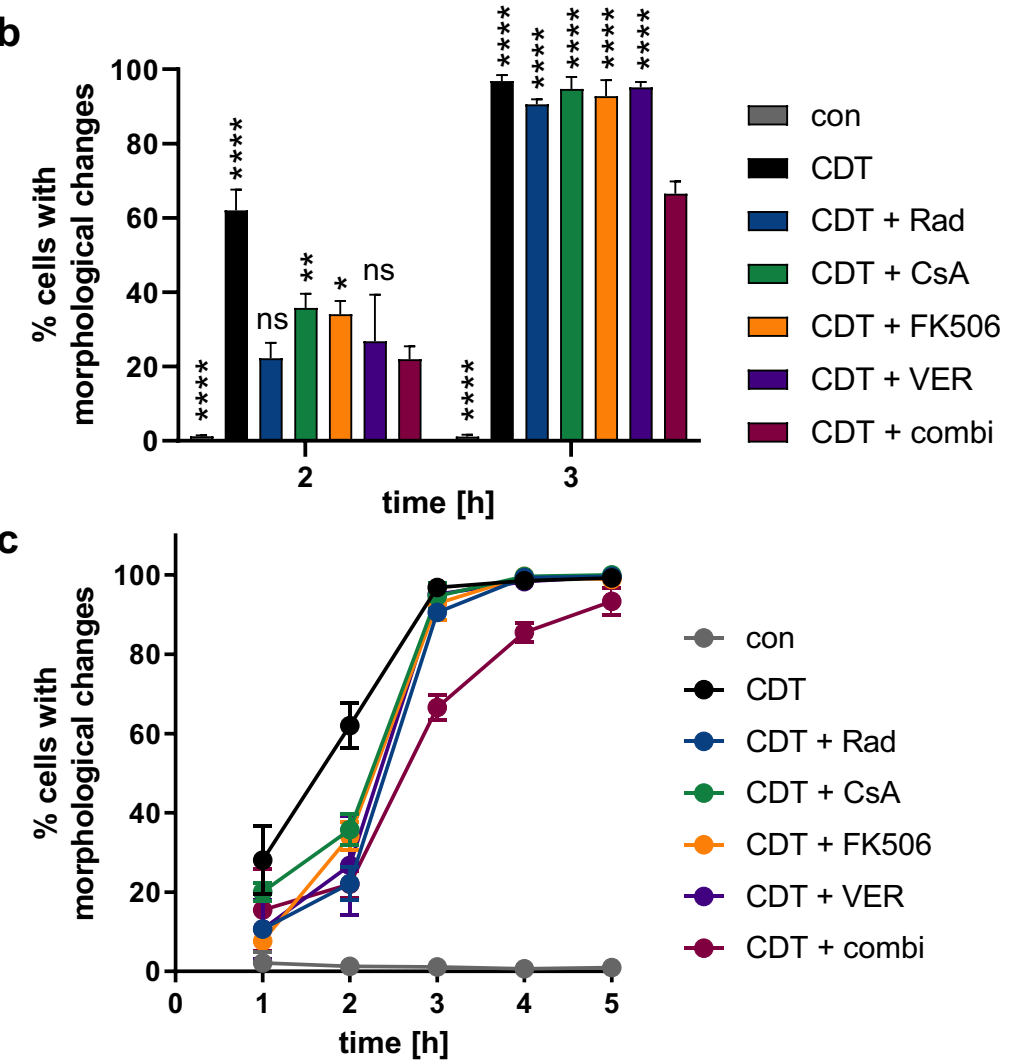

treatments, a quantification of Western blot signals was performed with normalization of Western blot signal to the protein loading. Figure $2 \mathrm{c}$ comprises the results of 3 independent experiments and demonstrates a significant inhibitory effect of the combination of inhibitors in the higher concentration on the intoxication of $\mathrm{CaCo}-2$ cells with CDT.
TEER measurements were performed to analyze the epithelial integrity of confluently grown $\mathrm{CaCo}-2$ monolayers after treatment with CDT or C2 toxin in the presence of the inhibitor combination (Fig. 3). Both, CDT and $\mathrm{C} 2$ toxin caused a strong reduction in TEER, which was delayed by the inhibitor combination. This inhibitory effect was 
a
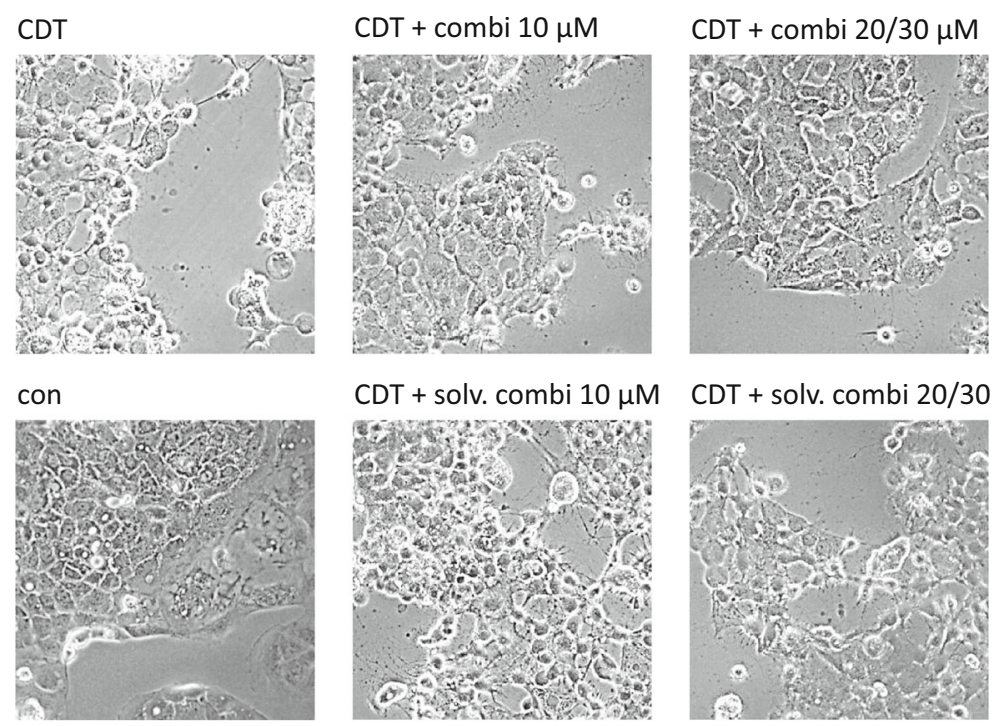

$\mathrm{CDT}+$ solv. combi $10 \mu \mathrm{M}$

CDT + solv. combi 20/30 $\mu \mathrm{M}$
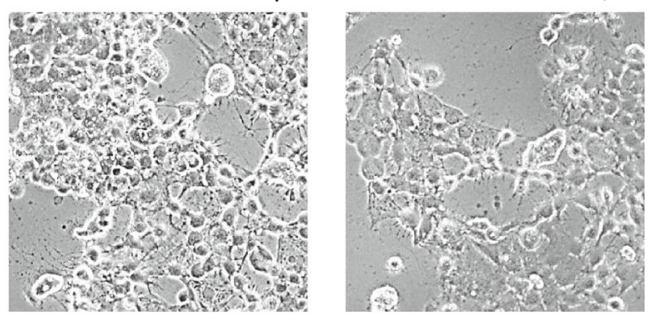

b
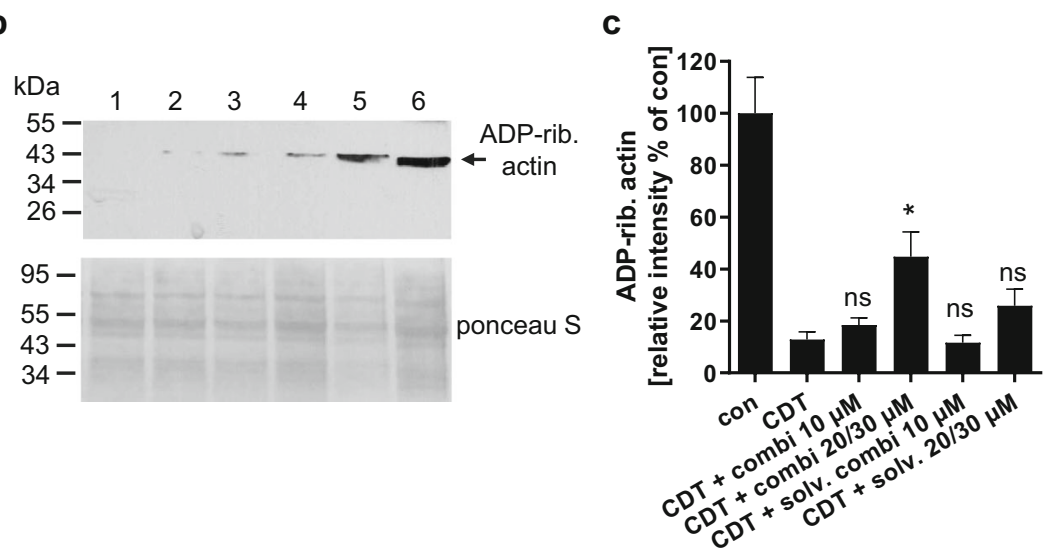

Fig. 2 Combined inhibition of Hsp90, Hsp70, Cyps, and FKBPs delays intoxication of human $\mathrm{CaCo}-2$ cells with CDT. $\mathrm{CaCo}-2$ cells were preincubated at $37^{\circ} \mathrm{C}$ for $30 \mathrm{~min}$ with the combination of the inhibitors in two different concentrations $(10 \mu \mathrm{M}$ each or $20 \mu \mathrm{M}$ CsA/FK506/ radicicol, $30 \mu \mathrm{M}$ VER). Cells were then challenged with $150 \mathrm{ng} / \mathrm{mL}$ $\mathrm{CDTa}+300 \mathrm{ng} / \mathrm{mL}$ CDTb. For control, cells were left untreated, treated only with CDT or with CDT in the presence of the respective solvent amount (ethanol or DMSO) of the respective inhibitor combinations. Cells were further incubated at $37^{\circ} \mathrm{C}$ for $4.5 \mathrm{~h}$. Subsequently, images were taken (a) and cells were lysed. (b) Cell lysates were incubated with fresh CDTa in the presence of biotin-labeled NAD ${ }^{+}$allowing ADPribosylation of G-actin that has not been modified during the incubation of cells. Cell lysates were subjected to SDS-PAGE followed by Western

more pronounced for $\mathrm{C} 2$ toxin in comparison with $\mathrm{CDT}$. The established inhibitor BafA1, which inhibits acidification of endosomes, was used as a control and led to a delayed toxin-induced reduction of TEER. After 3-5 h of incubation, BafA1 alone led to a decrease in TEER values (supplemental Fig. 2). Solvents of the inhibitors had no inhibitory effect in this assay (not shown). Cells treated with the inhibitor combination alone behaved comparable to untreated controls. blot analysis. Biotin-labeled G-actin was detected by Strep-POD and chemiluminescence. Transfer of protein by Western blotting was confirmed by ponceau S staining. Lane $1=\mathrm{CDT}$, Lane $2=\mathrm{CDT}+$ solv. combi $10 \mu \mathrm{M}$, Lane $3=\mathrm{CDT}+$ combi $10 \mu \mathrm{M}$, Lane $4=\mathrm{CDT}+$ solv. combi 20/30 $\mu \mathrm{M}$, Lane $5=$ CDT + combi 20/30 $\mu \mathrm{M}$, Lane $6=$ con. (c) Western blot signals were quantified by densitometry from 3 independent experiments. Values were normalized to protein loading, i.e., the ponceau $\mathrm{S}$ signal of each sample and in each experiment, values were normalized to untreated controls. Values are given as mean $\pm \operatorname{SEM}(n=6$, duplicates from 3 independent experiments). Significance was tested using one-way ANOVA followed by Dunnett's multiple comparison test. (* $p \leq 0.05$, ns, not significant vs CDT)

\section{Delay of C2 and CDT intoxication by inhibitor combination allows to reduce the concentrations of the individual inhibitors}

Since the combination of inhibitors alone impairs cell viability after longer incubation periods ( $>24 \mathrm{~h}$ ) (Ernst et al. 2018b), we tested whether the inhibitor combination is also effective if the concentration of each inhibitor is reduced. A clear delay in intoxication with $\mathrm{C} 2$ toxin was observed if inhibitors were 

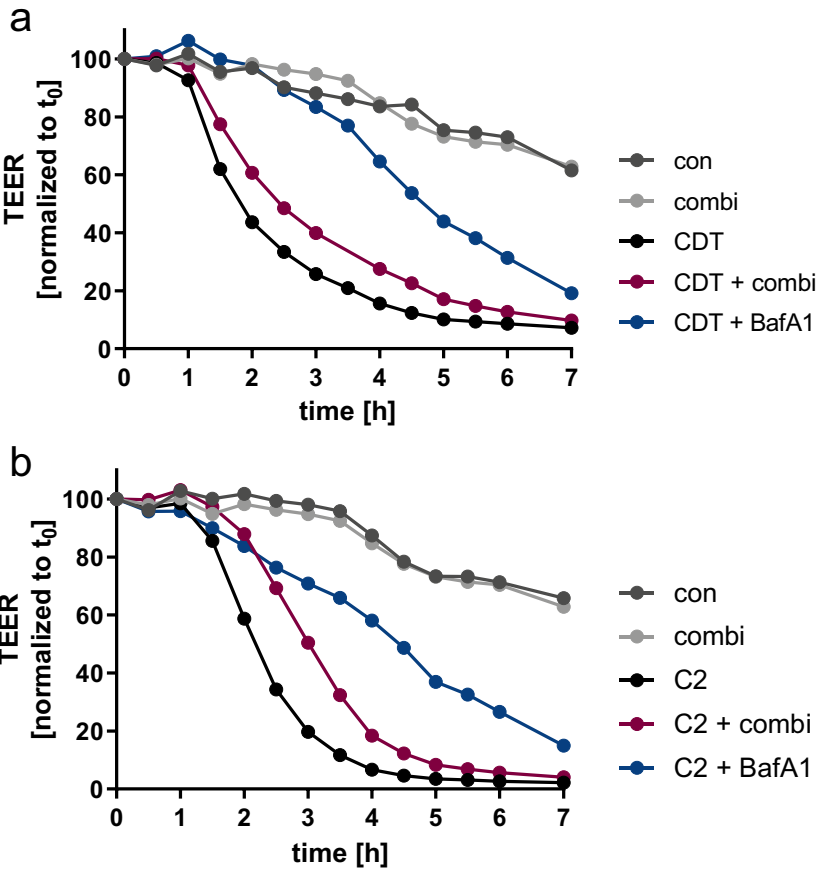

Fig. 3 Combination of chaperone inhibitors delays impairment of epithelial integrity of $\mathrm{CaCo}-2$ monolayers by $\mathrm{CDT}$ and $\mathrm{C} 2$ toxin. Caco2 monolayers were treated with the combination of inhibitors or their respective solvents for $30 \mathrm{~min}$. (a) CDT (30 ng/mL CDTa $+60 \mathrm{ng} / \mathrm{mL}$ $\mathrm{CDTb})$ or (b) $\mathrm{C} 2(50 \mathrm{ng} / \mathrm{mL} \mathrm{C} 2 \mathrm{I}+100 \mathrm{ng} / \mathrm{mL}$ C2IIa) were added and TEER was measured at indicated time points. For control, cells were left untreated or were treated only with the inhibitor combination. Values were normalized to $t_{0}$ values $\left(t_{0}=100 \%\right)$. Single values of one representative time course out of three independent experiments are shown

applied in concentrations down to $1 \mu \mathrm{M}$ (Fig. 4a). With the concentration series used in this experiment, a threshold was observed meaning that no inhibitory effect was detected when $0.1 \mu \mathrm{M}$ of each inhibitor was applied. For CDT, a concentration-dependency was also observed (Fig. 4b). The lowest concentration of the inhibitors, for which a delay was seen, was $10 \mu \mathrm{M}$. Interestingly, the recently described cytotoxic effect of the binding/translocation component CDTb in the absence of its enzyme component CDTa was not affected by the combination of chaperone inhibitors (Fig. 4c).

For $\mathrm{C} 2$ toxin, we also showed that treatment with lower concentrations of each inhibitor in combination $(10 \mu \mathrm{M}$ each $=10+10+10+10)$ still exhibits an enhanced protective effect when compared to a corresponding concentration of $40 \mu \mathrm{M}$ of each single inhibitor (Fig. 5a, b). Moreover, $10 \mu \mathrm{M}$ of inhibitor combination ( $10 \mu \mathrm{M}$ each) protected cells better than application of single inhibitors at a concentration of $10 \mu \mathrm{M}$ (Fig. 5c). The inhibitor combination was also superior when applied at lower concentrations ( $5 \mu \mathrm{M}$ each) compared to $20 \mu \mathrm{M}$ of each single inhibitor (supplemental Fig. 3). Comparing the effect of single inhibitors in concentrations that would correspond to the combination used before $(20+$ $20+20+30=90 \mu \mathrm{M}$ ) was not analyzed because inhibitors at
$90 \mu \mathrm{M}$ either impaired cell viability or were not soluble (Fig. 5d, supplemental Fig. 4).

Up to now, in every intoxication experiment, cells were pre-incubated with inhibitors for $30 \mathrm{~min}$. Then, toxin was added with the inhibitors still present in the cell culture medium. Here, we showed that $\mathrm{C} 2$ intoxication was delayed even if inhibitors were removed after $30 \mathrm{~min}$ pre-incubation (Fig. 6). The observed inhibitory effect in samples with only preincubation was comparable to samples with a continuous inhibitor incubation.

\section{Inhibitory effect of inhibitor combination is most pronounced for $\mathrm{C} 2$ intoxication compared to CDT and iota intoxication of cells}

The effect of the inhibitor combination in two different concentrations on $\mathrm{C} 2, \mathrm{CDT}$, and iota intoxication of cells was tested. The time courses of intoxication in Fig. 7 show that the inhibitory effect was most obvious for $\mathrm{C} 2$ intoxication in both concentrations tested. A slight delaying effect of the lower inhibitor concentration and a clear effect of the higher concentration were observed for CDT intoxication. For the iota toxin, only the higher inhibitor concentration delayed the intoxication of cells.

\section{Discussion}

Bacterial AB-type toxins are important virulence factors that cause severe diseases like cholera, whooping cough, or diphtheria. The clostridial $\mathrm{C} 2$ and iota toxin cause enterotoxicity in animals like calves and lambs and therefore pose a threat to livestock health and survival (Kurazono et al. 1987; Songer 1996). CDT harbors medical relevance in humans (Papatheodorou et al. 2018). C. difficile infections (CDI) present one of the most common healthcare-associated infections. CDI can elicit gastrointestinal symptoms ranging from diarrhea to pseudomembranous colitis and in most severe cases to toxic megacolon and sepsis. These symptoms are caused by the secreted AB-type toxins A (TcdA) and B (TcdB) (Papatheodorou et al. 2018). The emerging of hypervirulent $C$. difficile strains aggravates the threat to patients and complicates the already difficult treatment (Gerding et al. 2014; Papatheodorou et al. 2018). Hyper-virulent $C$. difficile strains show increases in toxin secretion, antibiotic resistance, morbidity, and mortality as well as reoccurrence of symptoms. Moreover, these strains produce CDT as an additional toxin to TcdA and TcdB (Gerding et al. 2014). CDT ADPribosylates G-actin in target cells which leads to Factin depolymerization and rounding of adherent cells. This further contributes to the impairment of the 
Fig. 4 Reduced concentrations of inhibitors still delay the

intoxication of cells with $\mathrm{C} 2$ toxin and CDT if applied in

combination. Vero cells were preincubated with the combination of inhibitors in different concentrations. (a) $\mathrm{C} 2$ toxin $(50 \mathrm{ng} / \mathrm{mL}+$ $100 \mathrm{ng} / \mathrm{mL}$ C2IIa) was added. Bar graph shows the percentage of cells with morphological changes determined from images taken after $2 \mathrm{~h}$ of $\mathrm{C} 2$ incubation. (b) CDT was added $(50 \mathrm{ng} / \mathrm{mL}$ CDTa $+100 \mathrm{ng} / \mathrm{mL}$ CDTb). Bar graph shows the percentage of intoxicated cells after $3 \mathrm{~h}$ of CDT incubation. Values are given as mean $\pm \mathrm{SD}(n=3)$. Significance was tested using one-way ANOVA followed by Dunnett's multiple comparison test. (**p $\leq 0.01$, $* * * * p \leq 0.0001, \mathrm{~ns}$, not significant vs CDT). (c) Vero cells were pre-incubated at $37^{\circ} \mathrm{C}$ for $30 \mathrm{~min}$ with the combination of the inhibitors $(10 \mu \mathrm{M}$ each) or their corresponding solvents. For control, cells were left untreated. CDTb $(600 \mathrm{ng} / \mathrm{mL})$ was added and images were taken after $1 \mathrm{~h}$. Percentage of cells with morphological changes, i.e., cell rounding were determined from images.

Values are given as mean $\pm \mathrm{SD}$ $(n=6)$. Significance was tested using one-way ANOVA followed by Dunnett's multiple comparison test. (ns, not significant vs $\mathrm{CDTb})$ a
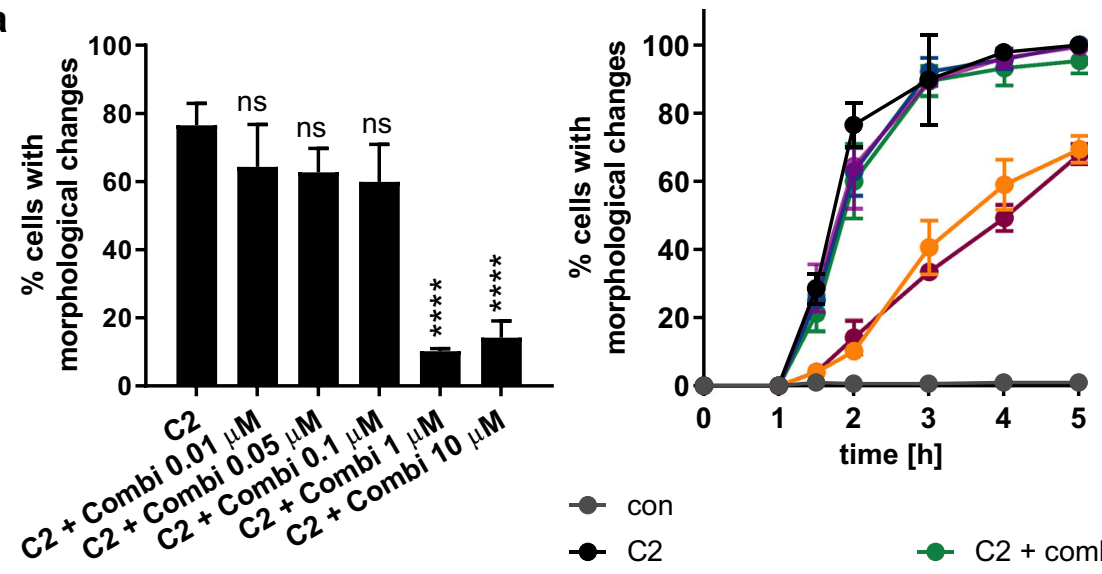

- con

- $\mathrm{C} 2-\mathrm{C} 2+$ combi $0.1 \mu \mathrm{M}$

- $\mathrm{C} 2+$ combi $0.01 \mu \mathrm{M}-\mathrm{C} 2+\operatorname{combi} 1 \mu \mathrm{M}$

- $\mathrm{C} 2+$ combi $0.05 \mu \mathrm{M} \rightarrow \mathrm{C} 2+$ combi $10 \mu \mathrm{M}$

b
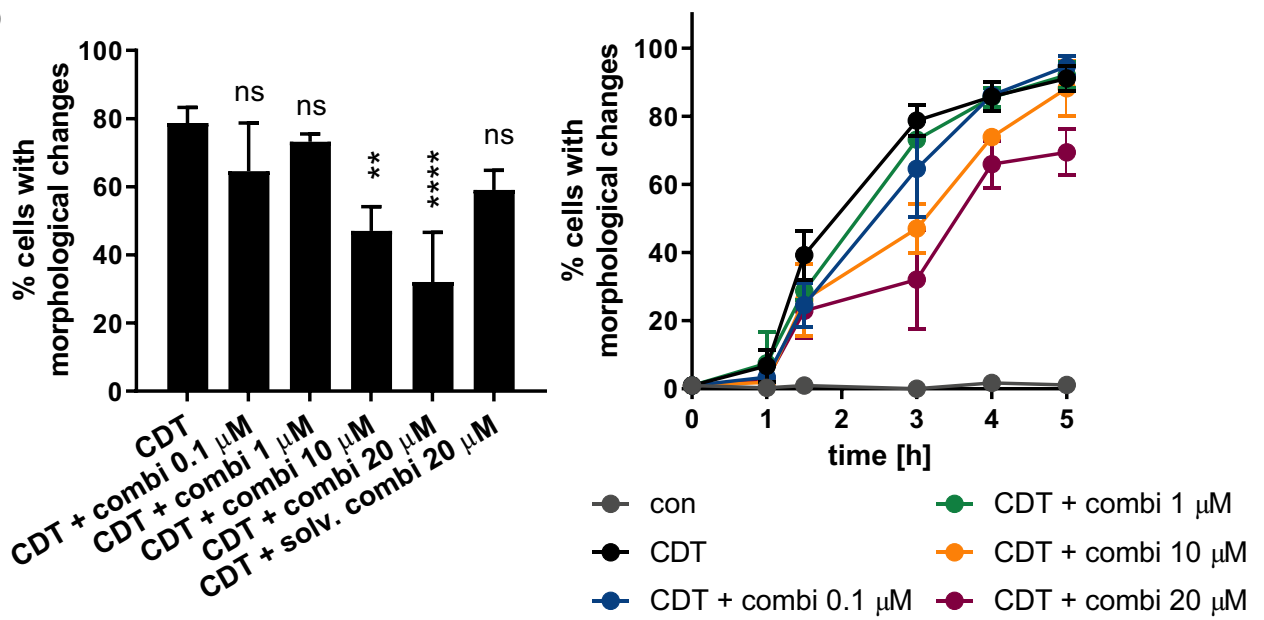

C

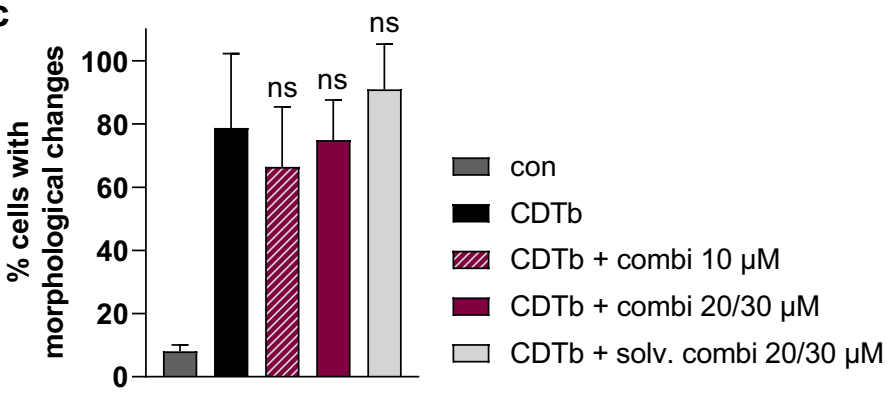

intestinal barrier which can be experimentally demonstrated by TEER measurements of epithelial cell layers. Additionally, CDT elicits the formation of microtubulebased protrusions in target cells (Schwan et al. 2009, 2011). Thereby, adherence of $C$. difficile to cells is enhanced in vitro and in vivo, and colonization of the gut is improved.

Currently, $C$. difficile infection is treated with specific antibiotics. Moreover, an antibody against TcdB is available. Since the secreted toxins are the cause of disease, further therapeutic strategies are required that are targeted at the toxins. Pharmacological inhibition of chaperones and PPIases protects cells from intoxication with CDT, C2 and iota toxin, and several other toxins (Ernst et al. 2017b). We showed that CDT, C2, and iota toxin directly bind to Hsp90, Hsp/c 70, and different isoforms of Cyps (CypA, Cyp40) and FKBPs (FKBP51, FKBP52) (Kaiser et al. 2009, 2011, 2012; Ernst et al. 2015, 2016, 2017a). Table 1 gives an overview of toxins that are dependent or independent of Hsps or PPIases. Inhibitors of these chaperones/PPIases specifically inhibited the membrane translocation of the toxins' 
a

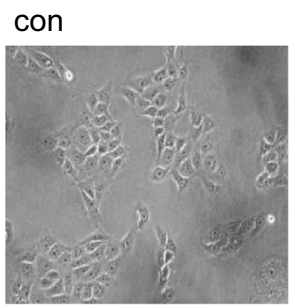

$\mathrm{C} 2+\operatorname{Rad} 40 \mu \mathrm{M}$

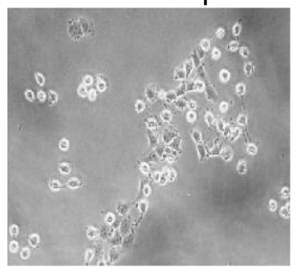

C2 + FK506 $40 \mu \mathrm{M}$

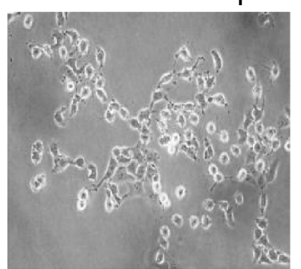

b

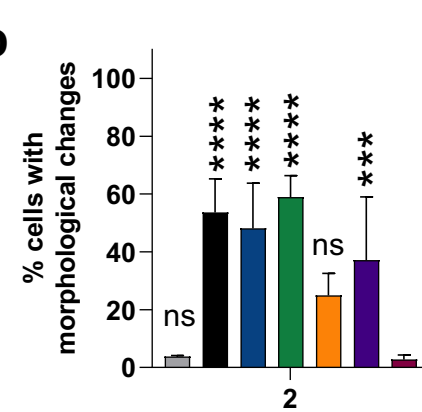

c
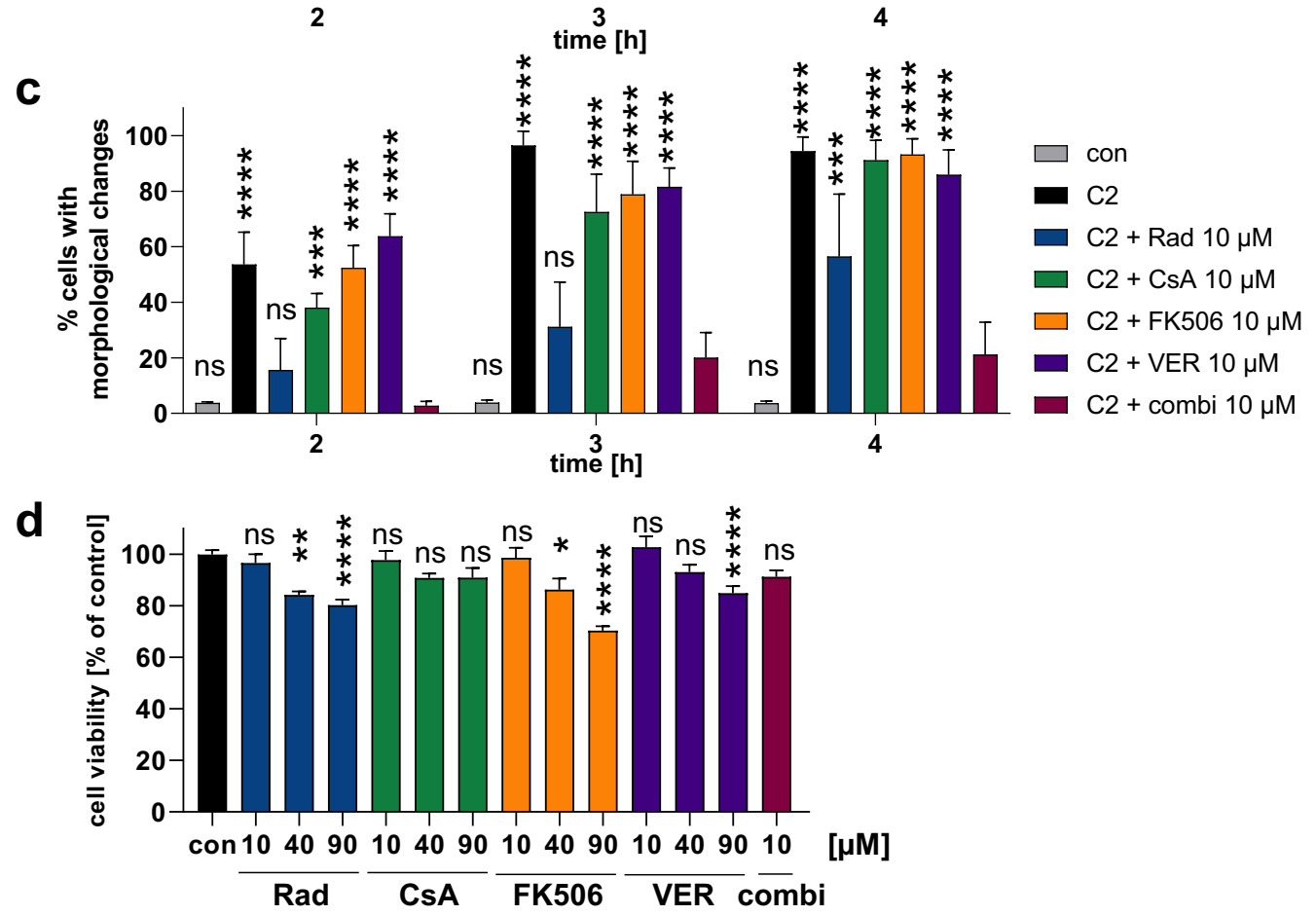

$\mathrm{C} 2+$ combi $10 \mu \mathrm{M}$

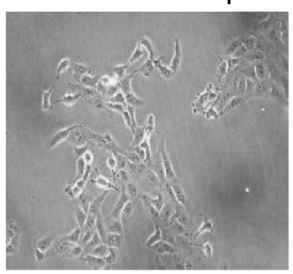

$\mathrm{C} 2+\operatorname{Rad} 10 \mu \mathrm{M}$

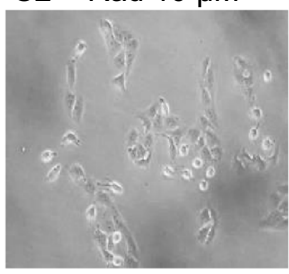

$\mathrm{C} 2+\mathrm{CsA} 10 \mu \mathrm{M}$

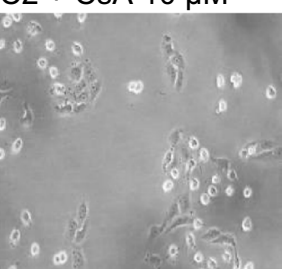

C2 + FK506 $10 \mu \mathrm{M}$

C2 + VER $10 \mu \mathrm{M}$
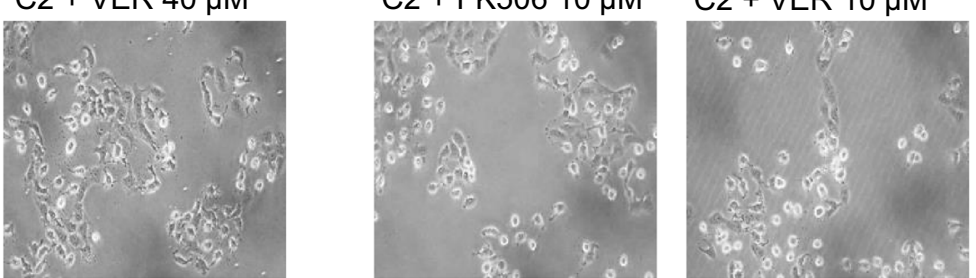

$\begin{array}{rrrr}* \\ * \\ * \\ * \\ * \\ * & * & * & * \\ * & * \\ * & * \\ *\end{array}$

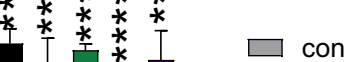

П

- $\mathrm{C} 2+\operatorname{Rad} 40 \mu \mathrm{M}$

$\square \mathrm{C} 2+\mathrm{CsA} 40 \mu \mathrm{M}$

$\square \mathrm{C} 2+\mathrm{FK} 50640 \mu \mathrm{M}$ ns ns

C2 + Rad $10 \mu \mathrm{M}$

+ CsA $10 \mu \mathrm{M}$

C2 + VER $10 \mu \mathrm{M}$

$\mathrm{C} 2+$ combi $10 \mu \mathrm{M}$ 
Fig. 5 Inhibitor combination protects cells from $\mathrm{C} 2$ intoxication in reduced concentrations compared to single inhibitors. Vero cells were pre-incubated with single inhibitors (Rad, CsA, FK506, VER, $40 \mu \mathrm{M}$, or $10 \mu \mathrm{M})$ or with the combination of inhibitors $(10 \mu \mathrm{M}$ of each inhibitor). $\mathrm{C} 2$ toxin was added (50 ng/mL C2I + $100 \mathrm{ng} / \mathrm{mL}$ C2IIa) and cell morphology was monitored. (a) Cell images are shown exemplarily after $3 \mathrm{~h}$ of incubation with $\mathrm{C} 2$ toxin. Percentage of cells with morphological changes was determined from cell images. For better visualization, comparison of $40 \mu \mathrm{M}$ of single inhibitors vs $10 \mu \mathrm{M}$ of inhibitor combination are shown in (b) and comparison of $10 \mu \mathrm{M}$ of single inhibitors vs $10 \mu \mathrm{M}$ of inhibitor combination are shown in (c). Values for con, C2, and C2+ combi $10 \mu \mathrm{M}$ are identical in both graphs. Values are given as mean $\pm \mathrm{SD}$ $(n=3)$. Significance was tested using two-way ANOVA followed by Dunnett's multiple comparison test. $(* * * * p \leq 0.0001$, **** $p \leq 0.001$, ns, not significant vs C2 + combi $10 \mu \mathrm{M}$ ). (d) Vero cells were incubated with Rad, CsA, FK506, VER, or the combination of all four inhibitors at indicated concentrations for $6 \mathrm{~h}$. Cell images were taken. Then, medium was exchanged to remove precipitation in the inhibitor samples and cell viability was measured by MTS assay. Values are given as mean $\pm \mathrm{SEM}$ ( $n=4$ (triplicates from 4 independent experiments)). Significance was tested using one-way ANOVA followed by Dunnett's multiple comparison test. $(* * * * p \leq 0.0001, * * * p \leq 0.001$, $* p \leq 0.05$, ns, not significant vs con)

enzyme components from endosomes to the cytosol (Fig. 8). Other steps of toxin uptake or mode of action like receptor-binding or in vitro enzyme activity were not affected by the inhibitors. Moreover, we recently showed that combining individual chaperone inhibitors has an enhanced protective effect against the intoxication with C2 toxin (Ernst et al. 2018b).
In this study, we extended these findings and demonstrated that the combination of chaperone/PPIase inhibitors has an enhanced protective effect against the medically relevant CDT. This inhibitory effect was shown by analyzing CDT-induced changes in morphology, ADPribosylation status of actin in $\mathrm{CaCo}-2$ cells, and transepithelial resistance of $\mathrm{CaCo}-2$ monolayers. Although this enhanced protective effect was statistically significant, we observed that the inhibitor combination exerts a stronger protection against $\mathrm{C} 2$ toxin compared to CDT and iota toxin. C2, CDT, and iota share a similar structure and uptake mechanism. However, several differences between $\mathrm{C} 2$ and iota-like toxins that amongst others include iota toxin and CDT have been described. For example, iota toxin and CDT bind to the same receptor, the LSR (Papatheodorou et al. 2011, 2018), while C2 toxin binds to carbohydrate structures on the cell surface (Eckhardt et al. 2000). The enzyme component of C2 toxin translocates from early endosomes, the enzyme component of iota toxin from intermediate endosomes, and requires a membrane potential gradient (Gibert et al. 2007). Moreover, during the last years, it has been described that the binding/translocation components of iota toxin and CDT show a cytotoxic effect that is independent of their enzyme components (Nagahama et al. 2011; Fischer et al. 2018, 2020; Kronhardt et al. 2018; Korbmacher et al. 2020). We observed that high concentrations of CDTb or $\mathrm{Ib}(>200-400 \mathrm{ng} / \mathrm{mL})$ cause
Fig. 6 Pre-incubation of cells with inhibitor combination is sufficient for delaying $\mathrm{C} 2$ intoxication. Vero cells were preincubated with the inhibitor combination in different concentrations. One set of samples (left) was immediately treated with $\mathrm{C} 2$ toxin $(50 \mathrm{ng} / \mathrm{mL} \mathrm{C} 2 \mathrm{I}+100 \mathrm{ng} /$ $\mathrm{mL}$ C2IIa), in the other set (right) the inhibitor-containing medium was removed, replaced by fresh medium without inhibitors and then, $\mathrm{C} 2$ toxin was added in the same concentration as in the other set. Percentage of intoxicated cells was determined from images. a Percentage of cells with morphological changes after $1.5 \mathrm{~h}$ of intoxication. Significance was tested using two-way ANOVA followed by Dunnett's multiple comparison test. $(* * * * p \leq 0.0001$ vs CDT). $\mathbf{b}$ Time course of intoxication. Values are given as mean $\pm \mathrm{SD}(n=3)$

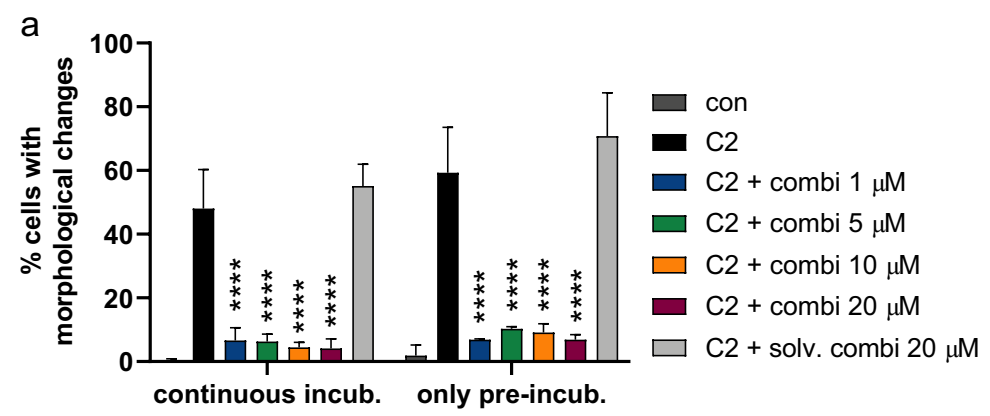

b
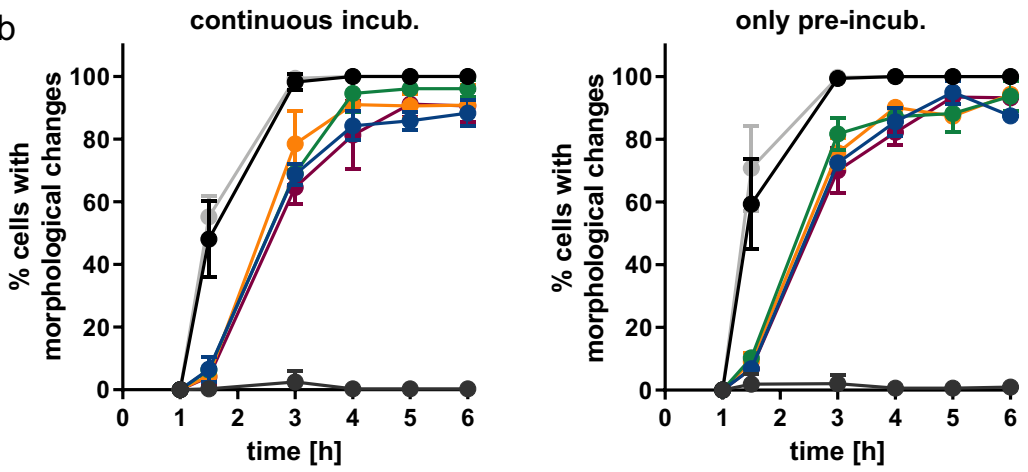

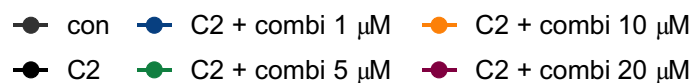




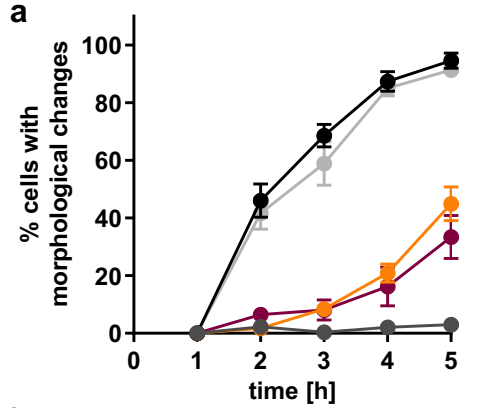

b

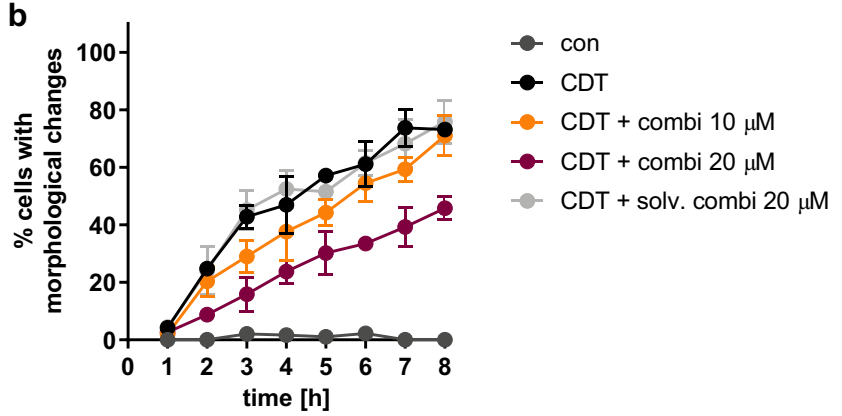

C

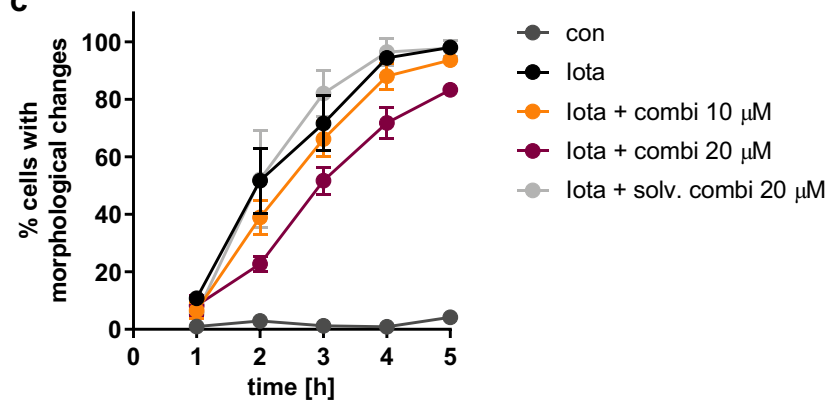

Fig. 7 Protective effect of inhibitor combination is most pronounced for $\mathrm{C} 2$ intoxication of cells compared to CDT and iota intoxications. Vero cells were pre-incubated with inhibitor combinations (10 $\mu \mathrm{M}$ Rad, CsA, FK506, and VER or $20 \mu \mathrm{M}$ Rad, CsA, FK506, and $30 \mu \mathrm{M}$ VER). For control, cells were left untreated or treated with the amount of solvents that corresponds to the higher inhibitor concentrations $(20 / 30 \mu \mathrm{M})$. Cells were then challenged with (a) $50 \mathrm{ng} / \mathrm{mL} \mathrm{C} 2 \mathrm{I}+100 \mathrm{ng} / \mathrm{mL}$ C2IIa, (b) $35 \mathrm{ng} / \mathrm{mL} \mathrm{CDTa}+70 \mathrm{ng} / \mathrm{mL} \mathrm{CDTb}$, or (c) $25 \mathrm{ng} / \mathrm{mL} \mathrm{Ia}+50 \mathrm{ng} / \mathrm{mL} \mathrm{Ib}$. Percentage of cells with morphological changes was determined from images. Values are given as mean $\pm \operatorname{SD}(n=3)$

rapid cell rounding of Vero cells and decrease of cell viability in the absence of CDTa or Ia (Fischer et al. 2018, 2020; Korbmacher et al. 2020). Moreover, pore formation by $\mathrm{CDTb}$ in black lipid bilayers and living CaCo-2 cells was shown (Kronhardt et al. 2018; Korbmacher et al. 2020; Fischer et al. 2020). Here, we showed that the cytotoxic CDTb effect was not inhibited by the combination of the chaperone inhibitors, which might be one reason why the inhibitory effect of the inhibitor combination is weaker on CDT compared to C2 toxin.

Despite this weaker effect on CDT compared to $\mathrm{C} 2$ toxin, a delay in intoxication of $\sim 2 \mathrm{~h}$ could still be relevant in context of clinical symptoms. Symptoms of
CDI last for longer time periods than analyzed in this study (days vs hours). Nevertheless, extrapolation of toxin concentrations and time courses of intoxication from cell culture to the in vivo situation cannot be done one-to-one. The effectiveness of chaperone inhibitors as an anti-toxin strategy with protective effects has to be further investigated in an animal model, e.g., the intestinal loop model in mice (Fischer et al. 2020). To improve protective effects over longer time periods, i.e., days, a repetitive application of low-dosed inhibitors is also conceivable. Moreover, anti-toxin strategies are not supposed to replace but rather to support the existing therapeutic strategies. Thereby, the disease can be tackled on different levels: antibiotics to eliminate toxinproducing bacteria, toxin antibodies to neutralize "free" unbound toxin, and inhibitors (e.g., chaperone inhibitors) to protect cells from toxin molecules that have been internalized already.

Moreover, we showed that the concentration of the individual inhibitors could be reduced to achieve a protective effect against CDT and $\mathrm{C} 2$ toxin if inhibitors are applied in combination. In fact, the inhibitor combination still showed an enhanced protective effect against $\mathrm{C} 2$ toxin when compared to increased concentrations of the single inhibitors, i.e., $40 \mu \mathrm{M}$ (or $20 \mu \mathrm{M}$ ) of single inhibitors vs $10 \mu \mathrm{M}$ (or $5 \mu \mathrm{M}$ ) of each inhibitor in combination. For $\mathrm{C} 2$ toxin, pre-incubation of cells with the inhibitor combination was sufficient to protect cells from intoxication. These findings suggest that inhibitor concentrations and exposure times could also be reduced in potential future therapeutic approaches which might reduce the risk of side effects. Interestingly, CsA and FK506 are licensed immunosuppressive drugs applied to patients for example after organ transplantation (Liu et al. 1991). Rad and VER have been tested in anti-tumor treatment which revealed some side effects ( $\mathrm{Li}$ and Buchner 2013; Schlecht et al. 2013). Besides reduction of concentration and duration of treatment, local application strategies and development of novel inhibitor derivative with improved safety profiles might also help to lower adverse effects.

Moreover, we and others showed that not only clostridial binary toxins but several other toxins depend on chaperones and PPIases (Lang et al. 2014; Ernst et al. 2017b). These toxins are amongst others diphtheria toxin (Schuster et al. 2017), cholera toxin (Burress et al. 2014, 2019; Kellner et al. 2019), and pertussis toxin (Ernst et al. 2018a) which are important virulence factors and the causative agents of severe diseases (Table 1). Comparable to $C$. difficile-associated diseases, therapeutic options for these diseases are limited, and novel approaches based on chaperones and PPIases might provide the possibility of a more universal therapeutic strategy. 


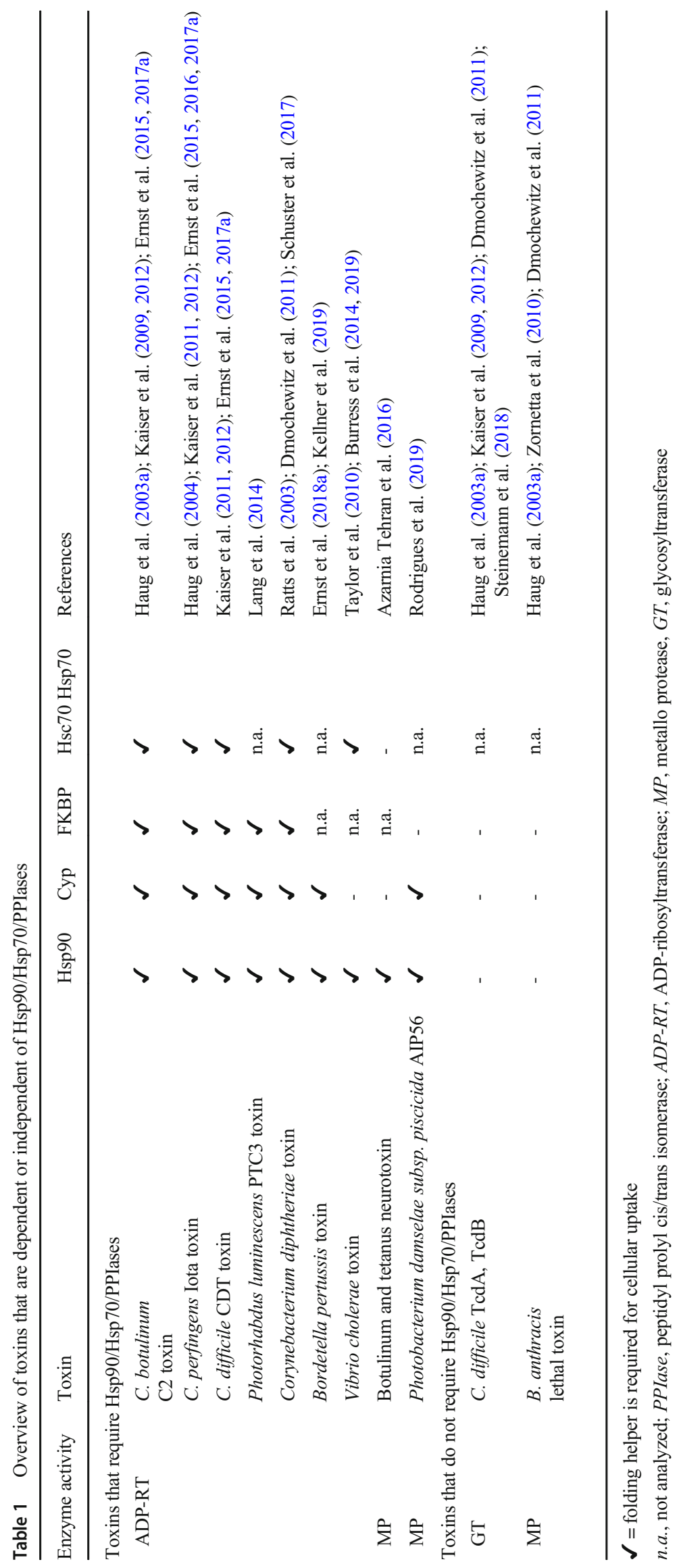




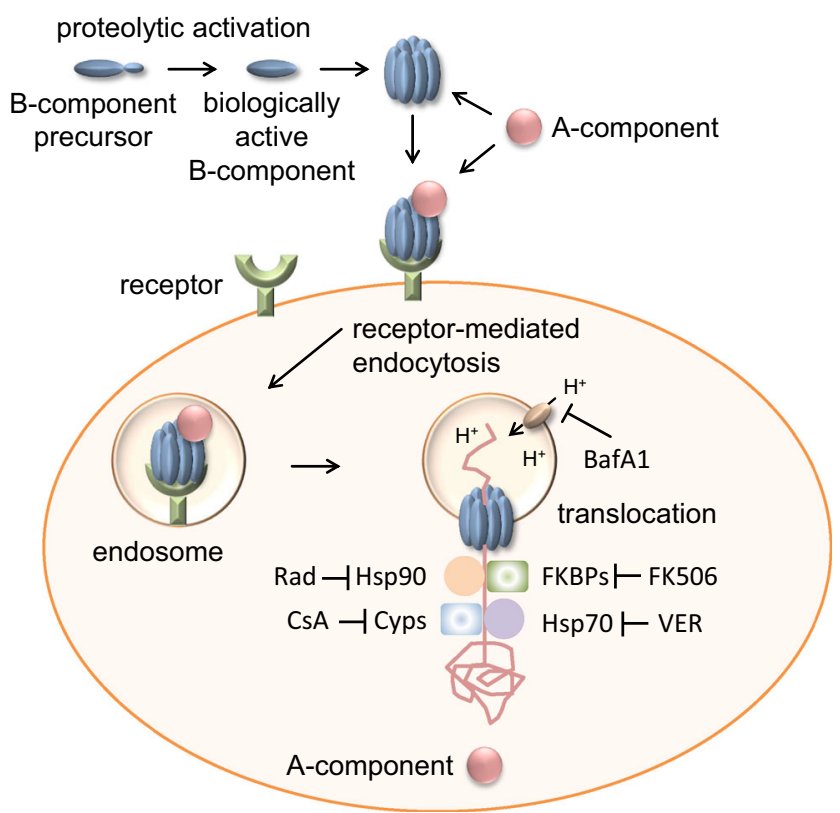

Fig. 8 Uptake mechanism of clostridial binary toxins CDT, C2, and iota toxin. After proteolytic activation, the B-component forms heptamers and binds to a cell surface receptor. The A-component binds to the heptamer and the complex is taken up by receptor-mediated endocytosis. Acidification of the endosomal lumen leads to insertion of the Bheptamer into the endosomal membrane thereby forming a pore through which the partially unfolded A-component translocates into the cytosol. This translocation step is facilitated by cellular protein folding helper enzymes Hsp90, Hsp70, Cyps, and FKBPs. Inhibition of these host cell factors by specific pharmacological inhibitors protects cells from intoxication with CDT, C2, and iota toxins. Here, we show that combining these inhibitors has an enhanced protective effect on intoxication with clostridial binary toxins compared to application of individual inhibitors. BafA1, bafilomycin A1; FKBPs, FK506-binding proteins; Cyps, cyclophilins; Rad, radicicol; CsA, cyclosporine A; VER, VER-155008

Supplementary Information The online version contains supplementary material available at https://doi.org/10.1007/s00210-020-02029-3.

Acknowledgments Anna Anastasia is thanked for excellent technical assistance. Klaus Aktories and Michel Popoff are thanked for providing CDT and iota toxin, respectively.

Authors' contribution $\mathrm{KE}$ designed and supervised the study and wrote the manuscript. JS and MB conducted and analyzed experiments. HB supervised the study. All authors read and approved the manuscript. The authors declare that all data were generated in-house and that no paper mill was used.

Funding Open Access funding enabled and organized by Projekt DEAL. This work was financially supported by the Medical Faculty Ulm (Baustein 3.2 to KE). KE is a fellow of the Margarete von Wrangell Habilitation program (Ministry of Science, Research and the Arts, Baden-Wuerttemberg, European Social Funds). MB is a member of the DFG Research Training Group Pulmosens GRK2203.
Data availability All data generated or analyzed during this study are included in this published article.

\section{Compliance with ethical standards}

Conflict of interest The authors declare that they have no conflict of interest.

Ethics approval Not applicable

Consent for publication Not applicable

Code availability Not applicable

Open Access This article is licensed under a Creative Commons Attribution 4.0 International License, which permits use, sharing, adaptation, distribution and reproduction in any medium or format, as long as you give appropriate credit to the original author(s) and the source, provide a link to the Creative Commons licence, and indicate if changes were made. The images or other third party material in this article are included in the article's Creative Commons licence, unless indicated otherwise in a credit line to the material. If material is not included in the article's Creative Commons licence and your intended use is not permitted by statutory regulation or exceeds the permitted use, you will need to obtain permission directly from the copyright holder. To view a copy of this licence, visit http://creativecommons.org/licenses/by/4.0/.

\section{References}

Aktories K, Wegner A (1992) Mechanisms of the cytopathic action of actin-ADP-ribosylating toxins. Mol Microbiol 6:2905-2908

Aktories K, Bärmann M, Ohishi I, Tsuyama S, Jakobs KH, Habermann E (1986) Botulinum C2 toxin ADP-ribosylates actin. Nature 322:390 392. https://doi.org/10.1038/322390a0

Azarnia Tehran D, Pirazzini M, Leka O et al (2016) Hsp90 is involved in the entry of clostridial neurotoxins into the cytosol of nerve terminals. Cell Microbiol. https://doi.org/10.1111/cmi.12647

Barth H, Ernst K (2016) Chaperones and ADP-ribosylating bacterial toxins. In: Gopalakrishnakone P, Stiles B, Alape-Girón A et al (eds) Microbial Toxins. Springer, Dordrecht, pp 1-22

Barth H, Stiles BG (2008) Binary actin-ADP-ribosylating toxins and their use as molecular Trojan horses for drug delivery into eukaryotic cells. Curr Med Chem 15:459-469

Barth H, Preiss JC, Hofmann F, Aktories K (1998) Characterization of the catalytic site of the ADP-ribosyltransferase Clostridium botulinum C2 toxin by site-directed mutagenesis. J Biol Chem 273:2950629511

Barth H, Blocker D, Behlke J et al (2000) Cellular uptake of Clostridium botulinum $\mathrm{C} 2$ toxin requires oligomerization and acidification. $\mathrm{J}$ Biol Chem 275:18704-18711. https://doi.org/10.1074/jbc. M000596200

Blöcker D, Barth H, Maier E et al (2000) The C terminus of component C2II of Clostridium botulinum $\mathrm{C} 2$ toxin is essential for receptor binding. Infect Immun 68:4566-4573

Burress H, Taylor M, Banerjee T, Tatulian SA, Teter K (2014) Co- and post-translocation roles for HSP90 in cholera intoxication. J Biol Chem 289:33644-33654. https://doi.org/10.1074/jbc.M114.609800

Burress H, Kellner A, Guyette J, Tatulian SA, Teter K (2019) HSC70 and HSP90 chaperones perform complementary roles in translocation of the cholera toxin A1 subunit from the endoplasmic reticulum to the 
cytosol. J Biol Chem 294:12122-12131. https://doi.org/10.1074/ jbc.RA119.008568

Dmochewitz L, Lillich M, Kaiser E, Jennings LD, Lang AE, Buchner J, Fischer G, Aktories K, Collier RJ, Barth H (2011) Role of CypA and Hsp90 in membrane translocation mediated by anthrax protective antigen. Cell Microbiol 13:359-373. https://doi.org/10.1111/j.14625822.2010.01539.x

Eckhardt M, Barth H, Blöcker D, Aktories K (2000) Binding of Clostridium botulinum $\mathrm{C} 2$ toxin to asparagine-linked complex and hybrid carbohydrates. J Biol Chem 275:2328-2334

Ernst K, Langer S, Kaiser E, Osseforth C, Michaelis J, Popoff MR, Schwan C, Aktories K, Kahlert V, Malesevic M, Schiene-Fischer C, Barth H (2015) Cyclophilin-facilitated membrane translocation as pharmacological target to prevent intoxication of mammalian cells by binary clostridial actin ADP-ribosylated toxins. J Mol Biol 427:1224-1238. https://doi.org/10.1016/j.jmb.2014.07.013

Ernst K, Liebscher M, Mathea S, Granzhan A, Schmid J, Popoff MR, Ihmels H, Barth H, Schiene-Fischer C (2016) A novel Hsp70 inhibitor prevents cell intoxication with the actin ADP-ribosylating Clostridium perfringens iota toxin. Sci Rep 6:20301. https://doi. org/10.1038/srep20301

Ernst K, Schmid J, Beck M, Hägele M, Hohwieler M, Hauff P, Ückert AK, Anastasia A, Fauler M, Jank T, Aktories K, Popoff MR, Schiene-Fischer C, Kleger A, Müller M, Frick M, Barth H (2017a) Hsp70 facilitates trans-membrane transport of bacterial ADPribosylating toxins into the cytosol of mammalian cells. Sci Rep 7: 2724. https://doi.org/10.1038/s41598-017-02882-y

Ernst K, Schnell L, Barth H (2017b) Host cell chaperones Hsp70/Hsp90 and Peptidyl-Prolyl Cis/trans Isomerases are required for the membrane translocation of bacterial ADP-Ribosylating toxins. Curr Top Microbiol Immunol 406:163-198. https://doi.org/10.1007/82 2016_14

Ernst K, Eberhardt N, Mittler A-K, Sonnabend M, Anastasia A, Freisinger S, Schiene-Fischer C, Malešević M, Barth H (2018a) Pharmacological cyclophilin inhibitors prevent intoxication of mammalian cells with Bordetella pertussis toxin. Toxins 10:181. https://doi.org/10.3390/toxins 10050181

Ernst K, Kling C, Landenberger M, Barth H (2018b) Combined pharmacological inhibition of Cyclophilins, FK506-binding proteins, Hsp90, and Hsp70 protects cells from Clostridium botulinum C2 toxin. Front Pharmacol 9. https://doi.org/10.3389/fphar.2018.01287

Fischer S, Popoff MR, Barth H (2018) Human alpha-defensin-1 protects cells from intoxication with Clostridium perfringens iota toxin. Pathog Dis 76. https://doi.org/10.1093/femspd/fty022

Fischer S, Ückert A-K, Landenberger M, Papatheodorou P, HoffmannRichter C, Mittler AK, Ziener U, Hägele M, Schwan C, Müller M, Kleger A, Benz R, Popoff MR, Aktories K, Barth H (2020) Human peptide $\alpha$-defensin-1 interferes with Clostridioides difficile toxins TcdA, TcdB, and CDT. FASEB J 34:6244-6261. https://doi.org/ 10.1096/fj.201902816R

Gerding DN, Johnson S, Rupnik M, Aktories K (2014) Clostridium difficile binary toxin CDT: mechanism, epidemiology, and potential clinical importance. Gut Microbes 5:15-27. https://doi.org/10.4161/ gmic. 26854

Gibert M, Marvaud JC, Pereira Y, Hale ML, Stiles BG, Boquet P, Lamaze C, Popoff MR (2007) Differential requirement for the translocation of clostridial binary toxins: iota toxin requires a membrane potential gradient. FEBS Lett 581:1287-1296. https://doi.org/10. 1016/j.febslet.2007.02.041

Haug G, Leemhuis J, Tiemann D, Meyer DK, Aktories K, Barth H (2003a) The host cell chaperone Hsp90 is essential for translocation of the binary Clostridium botulinum $\mathrm{C} 2$ toxin into the cytosol. J Biol Chem 278:32266-32274. https://doi.org/10.1074/jbc.M303980200

Haug G, Wilde C, Leemhuis J, Meyer DK, Aktories K, Barth H (2003b) Cellular uptake of Clostridium botulinum $\mathrm{C} 2$ toxin: membrane translocation of a fusion toxin requires unfolding of its dihydrofolate reductase domain. Biochemistry 42:15284-15291. https://doi.org/ 10.1021/bi0354278

Haug G, Aktories K, Barth H (2004) The host cell chaperone Hsp90 is necessary for cytotoxic action of the binary iota-like toxins. Infect Immun 72:3066-3068

Kaiser E, Pust S, Kroll C, Barth H (2009) Cyclophilin A facilitates translocation of the Clostridium botulinum $\mathrm{C} 2$ toxin across membranes of acidified endosomes into the cytosol of mammalian cells. Cell Microbiol 11:780-795. https://doi.org/10.1111/j.1462-5822.2009. 01291.x

Kaiser E, Kroll C, Ernst K, Schwan C, Popoff M, Fischer G, Buchner J, Aktories K, Barth H (2011) Membrane translocation of binary actinADP-ribosylating toxins from Clostridium difficile and Clostridium perfringens is facilitated by cyclophilin A and Hsp90. Infect Immun 79:3913-3921. https://doi.org/10.1128/IAI.05372-11

Kaiser E, Böhm N, Ernst K, Langer S, Schwan C, Aktories K, Popoff M, Fischer G, Barth H (2012) FK506-binding protein 51 interacts with Clostridium botulinum $\mathrm{C} 2$ toxin and FK506 inhibits membrane translocation of the toxin in mammalian cells. Cell Microbiol 14: 1193-1205. https://doi.org/10.1111/j.1462-5822.2012.01788.x

Kellner A, Taylor M, Banerjee T et al (2019) A binding motif for Hsp90 in the A chains of ADP-ribosylating toxins that move from the endoplasmic reticulum to the cytosol. Cell Microbiol:e13074. https://doi.org/10.1111/cmi.13074

Korbmacher M, Fischer S, Landenberger M, Papatheodorou P, Aktories K, Barth H (2020) Human $\alpha$-Defensin-5 efficiently neutralizes Clostridioides difficile toxins TcdA, TcdB, and CDT. Front Pharmacol 11. https://doi.org/10.3389/fphar.2020.01204

Kronhardt A, Schwan C, Maier E et al (2018) Clostridium difficile CDT toxin forms two different types of channels in lipid bilayer membranes. BAOJ Chem 3:035

Kurazono H, Hosokawa M, Matsuda H, Sakaguchi G (1987) Fluid accumulation in the ligated intestinal loop and histopathological changes of the intestinal mucosa caused by Clostridium botulinum $\mathrm{C} 2$ toxin in the pheasant and chicken. Res Vet Sci 42:349-353

Lang AE, Ernst K, Lee H, Papatheodorou P, Schwan C, Barth H, Aktories K (2014) The chaperone Hsp90 and PPIases of the cyclophilin and FKBP families facilitate membrane translocation of Photorhabdus luminescens ADP-ribosyltransferases. Cell Microbiol 16:490-503. https://doi.org/10.1111/cmi.12228

Li J, Buchner J (2013) Structure, function and regulation of the hsp90 machinery. Biom J 36:106-117. https://doi.org/10.4103/2319-4170. 113230

Liu J, Farmer JD, Lane WS et al (1991) Calcineurin is a common target of cyclophilin-cyclosporin a and FKBP-FK506 complexes. Cell 66: 807-815

Nagahama M, Umezaki M, Oda M, Kobayashi K, Tone S, Suda T, Ishidoh K, Sakurai J (2011) Clostridium perfringens iota-toxin b induces rapid cell necrosis ${ }^{\nabla}$. Infect Immun 79:4353-4360. https:// doi.org/10.1128/IAI.05677-11

Ohishi I (1983) Lethal and vascular permeability activities of botulinum $\mathrm{C} 2$ toxin induced by separate injections of the two toxin components. Infect Immun 40:336-339

Ohishi I, Miyake M, Ogura H, Nakamura S (1984) Cytopathic effect of botulinum C2 toxin on tissue-culture cells. FEMS Microbiol Lett 23: 281-284. https://doi.org/10.1111/j.1574-6968.1984.tb01078.x

Papatheodorou P, Zamboglou C, Genisyuerek S, Guttenberg G, Aktories K (2010) Clostridial glucosylating toxins enter cells via clathrinmediated endocytosis. PLoS One 5:e10673. https://doi.org/10. 1371/journal.pone.0010673

Papatheodorou P, Carette JE, Bell GW, Schwan C, Guttenberg G, Brummelkamp TR, Aktories K (2011) Lipolysis-stimulated lipoprotein receptor (LSR) is the host receptor for the binary toxin Clostridium difficile transferase (CDT). Proc Natl Acad Sci U S A 108:16422-16427. https://doi.org/10.1073/pnas.1109772108 
Papatheodorou P, Barth H, Minton N, Aktories K (2018) Cellular uptake and mode-of-action of Clostridium difficile toxins. Adv Exp Med Biol 1050:77-96. https://doi.org/10.1007/978-3-319-72799-8_6

Perelle S, Gibert M, Bourlioux P, Corthier G, Popoff MR (1997) Production of a complete binary toxin (actin-specific ADPribosyltransferase) by Clostridium difficile CD196. Infect Immun 65:1402-1407

Popoff MR, Rubin EJ, Gill DM, Boquet P (1988) Actin-specific ADPribosyltransferase produced by a Clostridium difficile strain. Infect Immun 56:2299-2306

Ratts R, Zeng H, Berg EA, Blue C, McComb ME, Costello CE, vanderSpek JC, Murphy JR (2003) The cytosolic entry of diphtheria toxin catalytic domain requires a host cell cytosolic translocation factor complex. J Cell Biol 160:1139-1150. https://doi.org/10. 1083/jcb.200210028

Reuner KH, Presek P, Boschek CB, Aktories K (1987) Botulinum C2 toxin ADP-ribosylates actin and disorganizes the microfilament network in intact cells. Eur J Cell Biol 43:134-140

Rodrigues IS, Pereira LMG, Lisboa J et al (2019) Involvement of Hsp90 and cyclophilins in intoxication by AIP56, a metalloprotease toxin from Photobacterium damselae subsp. piscicida. Sci Rep 9:9019. https://doi.org/10.1038/s41598-019-45240-w

Schering B, Bärmann M, Chhatwal GS et al (1988) ADP-ribosylation of skeletal muscle and non-muscle actin by Clostridium perfringens iota toxin. Eur J Biochem 171:225-229

Schiene-Fischer C (2014) Multidomain peptidyl prolyl cis/trans Isomerases. Biochim Biophys Acta 1850:2005-2016. https://doi. org/10.1016/j.bbagen.2014.11.012

Schleberger C, Hochmann H, Barth H, Aktories K, Schulz GE (2006) Structure and action of the binary $\mathrm{C} 2$ toxin from Clostridium botulinum. J Mol Biol 364:705-715. https://doi.org/10.1016/j.jmb.2006. 09.002

Schlecht R, Scholz SR, Dahmen H, Wegener A, Sirrenberg C, Musil D, Bomke J, Eggenweiler HM, Mayer MP, Bukau B (2013) Functional analysis of Hsp70 inhibitors. PLoS One 8:e78443. https://doi.org/ 10.1371/journal.pone.0078443

Schuster M, Schnell L, Feigl P, Birkhofer C, Mohr K, Roeder M, Carle S, Langer S, Tippel F, Buchner J, Fischer G, Hausch F, Frick M, Schwan C, Aktories K, Schiene-Fischer C, Barth H (2017) The Hsp90 machinery facilitates the transport of diphtheria toxin into human cells. Sci Rep 7:613. https://doi.org/10.1038/s41598-01700780-x

Schwan C, Stecher B, Tzivelekidis T, van Ham M, Rohde M, Hardt WD, Wehland J, Aktories K (2009) Clostridium difficile toxin CDT induces formation of microtubule-based protrusions and increases adherence of bacteria. PLoS Pathog 5:e1000626. https://doi.org/10. 1371/journal.ppat.1000626

Schwan C, Nölke T, Kruppke AS, Schubert DM, Lang AE, Aktories K (2011) Cholesterol- and sphingolipid-rich microdomains are essential for microtubule-based membrane protrusions induced by Clostridium difficile transferase (CDT). J Biol Chem 286:2935629365. https://doi.org/10.1074/jbc.M111.261925

Songer JG (1996) Clostridial enteric diseases of domestic animals. Clin Microbiol Rev 9:216-234

Steinemann M, Schlosser A, Jank T, Aktories K (2018) The chaperonin $\mathrm{TRiC} / \mathrm{CCT}$ is essential for the action of bacterial glycosylating protein toxins like Clostridium difficile toxins a and B. Proc Natl Acad Sci U S A 115:9580-9585. https://doi.org/10.1073/pnas. 1807658115

Stiles BG, Wilkins TD (1986) Purification and characterization of Clostridium perfringens iota toxin: dependence on two nonlinked proteins for biological activity. Infect Immun 54:683-688

Taylor M, Navarro-Garcia F, Huerta J, Burress H, Massey S, Ireton K, Teter K (2010) Hsp90 is required for transfer of the cholera toxin A1 subunit from the endoplasmic reticulum to the cytosol. J Biol Chem 285:31261-31267. https://doi.org/10.1074/jbc.M1 10.148981

Wegner A, Aktories K (1988) ADP-ribosylated actin caps the barbed ends of actin filaments. J Biol Chem 263:13739-13742

Wigelsworth DJ, Ruthel G, Schnell L, Herrlich P, Blonder J, Veenstra TD, Carman RJ, Wilkins TD, van Nhieu GT, Pauillac S, Gibert M, Sauvonnet N, Stiles BG, Popoff MR, Barth H (2012) CD44 promotes intoxication by the clostridial iota-family toxins. PLoS One 7: e51356. https://doi.org/10.1371/journal.pone.0051356

Zornetta I, Brandi L, Janowiak B, Dal Molin F, Tonello F, Collier RJ, Montecucco C (2010) Imaging the cell entry of the anthrax oedema and lethal toxins with fluorescent protein chimeras. Cell Microbiol 12:1435-1445. https://doi.org/10.1111/j.1462-5822.2010.01480.x

Publisher's note Springer Nature remains neutral with regard to jurisdictional claims in published maps and institutional affiliations. 